\section{DIGITAL COMMONS \\ @ UNIVERSITY OF SOUTH FLORIDA}

\section{ABO: Interactive Journal for Women in the Arts, 1640-1830}

Volume 2

Issue 2 Volume 2.2 (Fall 2012): Open Access

Article 7

2012

\title{
Staffing: 'The Part-Time Crisis in the Classroom'
}

Judith Bailey Slagle

East Tennessee State University, slagle@etsu.edu

Follow this and additional works at: https://digitalcommons.usf.edu/abo

Part of the Dramatic Literature, Criticism and Theory Commons, Educational Methods Commons, Feminist, Gender, and Sexuality Studies Commons, and the Literature in English, British Isles Commons

\section{Recommended Citation}

Slagle, Judith Bailey (2012) "Staffing: 'The Part-Time Crisis in the Classroom'," ABO: Interactive Journal for Women in the Arts, 1640-1830: Vol.2: Iss.2, Article 7.

http://dx.doi.org/10.5038/2157-7129.2.2.7

Available at: https://digitalcommons.usf.edu/abo/vol2/iss2/7

This Scholarship is brought to you for free and open access by Digital Commons @ University of South Florida. It has been accepted for inclusion in ABO: Interactive Journal for Women in the Arts, 1640-1830 by an authorized administrator of Digital Commons @ University of South Florida. For more information, please contact digitalcommons@usf.edu. 


\section{Staffing: 'The Part-Time Crisis in the Classroom'}

\section{Keywords}

adjunct, adjunct faculty, budgets, part-time, part-time faculty, post-doctoral, post-doctoral fellows, staffing, state of the profession

Creative Commons License

(c) (i) $\Theta$

This work is licensed under a Creative Commons Attribution-No Derivative Works 3.0 License. 
In 2008, my Department of English reached such a crisis in the ratio of part-time faculty to full time that as department chair I decided it was time to involve the university President. With only 25 tenured/tenure-track English faculty, and several of them on administrative assignments, along with a rising number of majors, we were covering $62 \%$ of our 1000-2000-level English courses with part-time faculty - often barely qualified to be in the classroom. In comparison, according to the most recent Delaware Cost Study, our peers were using 32\%. I found myself in the untenable position every fall of having to hire part-time faculty I said that I'd never hire again. My immediate supervisors understood the problem; they just didn't have the money needed to correct it.

So, with a blessing from the Dean and Provost, I put together a statistical presentation for the President, hoping that he would support a five-year staffing plan for the department. In addition to tenure-track replacements for any tenured faculty members retiring, etc., I asked for positions we'd never had before-post-doctoral fellows. My proposal was to staff

○ 3000-4000-level courses and 5000-level graduate courses with tenured/tenure-track faculty

○ 1000-2000-level courses with a mix of tenured/tenure-track faculty, post-doctoral fellows, lecturers, graduate TAs and experienced part-time adjuncts

The purpose of this inclusion of post-doctoral fellows was to support the university's Quality Enhancement Initiative by, particularly, improving the quality of freshman instruction.

Once the President saw our ratio statistics, he was appalled-he even turned to others in the room and asked, "how did this happen?" So what this did was set a 5-year plan in motion to change our quality of instruction in English. Now, unfortunately, we didn't get new tenure-track positions, only replacements; but we did get a reservoir of post-docs fresh out of $\mathrm{PhD}$ programs with significant teaching and research experience-and lots of enthusiasm. And because it was a 5-year plan, the President only had to invest the money in increments (about \$200,000 per Academic Year).

Clearly, this is still not an ideal situation. The ideal solution would be to support the market by opening a new tenure-track position with every university's growing enrollment. Although we now have 4 full-time lecturers in English and 7 post-docs, we still rely too heavily on part-time adjuncts. But it's better-we're down from $62 \%$ of our lower-division English taught by adjuncts to $37 \%$ - a huge improvement. And most of that improvement is a result of highly qualified postdoctoral fellows who benefit from additional experience as we benefit from their expertise. Until we gain tenure-track positions, this is probably the model we will follow. Even better is that the President and Provost have now required that every department provide a 5-year Staffing Plan to improve the quality of undergraduate instruction at our university. 